\title{
ANALISIS KEMAMPUAN MATEMATIS MAHASISWA PGSD TERHADAP PENGGUNAAN GEOGEBRA CLASSROOM DI ERA DAN PASCA PANDEMI COVID-19
}

\author{
Ira Asyura ${ }^{1}$, Ratna Dewi ${ }^{2}$ \\ ${ }^{1,2}$ STKIP Syekh Manshur, Jl. Raya Labuan KM 5 Cikoneng Kadulisung Pandeglang Banten \\ Email penulis pertama: ira.asyura@gmail.com
}

\begin{abstract}
This study was conducted to see the mathematical abilities of Elementary School Teacher Education students in using GeoGebra Classroom. The sample in this study were elementary school teacher education students STKIP Syekh Manshur semester 4. This study aims to describe the communication skills, connection skills and representation abilities of students in solving geometry and algebra problems in mathematics education II. This research uses descriptive qualitative research. The data collection method used is based on the analysis of mathematics data obtained after using the geogebra classroom. Students are constrained in making mathematical modeling so that there are still many who have achieved expression indicators in mathematical communication. Likewise with the ability of mathematical representation where there is confusion in modeling, but have been able to paint pictures and provide explanations. correctly. Meanwhile, the average connection ability provides answers according to the problem but is incomplete.
\end{abstract}

Keywords: GeoGebra Classroom; Communication; Connection; Representation

\begin{abstract}
Abstrak
Penelitian ini dilakukan untuk melihat kemampuan matematis mahasiswa Pendidikan Guru Sekolah Dasar terhadap penggunaan GeoGebra Classroom. Sampel pada penelitian ini adalah mahasiswa pendidikan guru sekolah dasar STKIP Syekh Manshur semester 4. Penelitian ini bertujuan untuk mendeskripsikan kemampuan komunikasi (communication), kemampuan koneksi (connection), dan kemampuan representasi (representation) mahasiswa dalam menyelesaikan soal geometri dan aljabar pada mata kuliah pendidikan matematika II. Penelitian ini menggunakan jenis penelitian deskriptif kualitatif. Metode pengumpulan data yang digunakan adalah metode tes yang terdapat pada GeoGebra Classroom. Berdasarkan data analisis kemampuan matematis yang diperoleh setelah menggunakan GeoGebra Classroom, mahasiswa terkendala dalam membuat permodelan matematika sehingga masih banyak yang belum mencapai indikator ekpresi dalam komunikasi matematis. Begitu juga dengan kemampuan representasi matematis dimana adanya kebingungan dalam permodelan, namun sudah mampu melukiskan gambar dan memberikan penjelasan dengan benar. Sementara, kemampuan koneksi rata-rata memberikan jawaban sesuai dengan permasalahan tetapi kurang lengkap.
\end{abstract}

Kata kunci: GeoGebra Classroom; Komunikasi; Koneksi; Representasi

\section{PENDAHULUAN}

WHO menetapkan semenjak 30 januari 2020 sebagai darurat kesehatan berskala global terkait wabah Covid-19. Hal ini tidak hanya berdampak pada aspek kesehatan dan perekonomian, tetapi juga pada dunia pendidikan. Dengan adanya instruksi untuk social distancing atau physical distancing dalam rangka menghambat penyebaran Covid-19, hampir semua kegiatan pembelajaran dan kegiatan yang sifatnya administrative dikerjakan secara jarak jauh. Pada tingkat perguruan tinggi, sistem perkuliahan dilakukan secara daring dan mahasiswa dapat belajar secara online di rumah masingmasing (Fitaloka, 2020).

Dampak yang ditimbulkan dari Pandemi Covid-19 terhadap pembelajaran meliputi: 1) perubahan pembelajaran tatap muka menjadi pembelajaran online; 2) pengingkatan penggunaan teknologi dalam pembelajaran; 3) peningkatan kemandirian belajar mahasiswa (Firman, 2020). Seiiring dengan perkembangan teknologi yang pesat dapat dimanfaatkan untuk mengembangkan dunia pendidikan 
Analisis Kemampuan Matematis Mahasiswa PGSD Terhadap Penggunaan Geogebra Classroom di Era dan Pasca

termasuk sebagai penunjang pembelajaran matematika yaitu sebagai media pembelajaran matematika terutama di saat pandemik ini. Media pembelajaran yang saat ini berkembang pesat dengan perangkat komputer dengan program-program yang relevan. Arsyad (2011: 4), media merupakan semua bentuk perantara yang digunakan oleh manusia untuk menyampaikan atau menyebarkan ide, gagaran, atau pendapat sehingga ide, gagasan, atau pendapat yang dikemukakan itu sampai kepada penerima yang dituju. Hal ini juga sejalan dengan penelitian sebelumnya, Asyura (2017: 214) mengemukakan bahwa penggunaan media pembelajaran interaktif dinyatakan efektif berdasarkan proses pembelajaran yang membaik, peningkatan hasil belajar dan aktivitas siswa menunjukkan peningkatan.

Salah satu program komputer yang dapat dimanfaatkan sebagai media pembelajaran matematika adalah GeoGebra. GeoGebra is an easy-to-use and versatile tool that seems especially useful for undergraduate college level courses like geometry or calculus. As a multi-platform open source software it is available for everyone everywhere which makes it easy to use this tool for homework assignments too. The export of html pages for creating interactive teaching materials can both support classroom demonstration for dynamic visualizations and active student participation through dynamic worksheets" (Hohenwarter et al., 2007). GeoGebra salah satu aplikasi yang mudah dalam penggunaanya. GeoGebra dapat di download dalam bentuk aplikasi maupun dapat diakses pada laman website https://www.geogebra.org/. Pada laman website, terdapat satu menu yaitu GeoGebra Classroom dimana penggunaannya seperti pada Google Classroom yang memuat materi ataupun dijadikan sebagai lembar kerja. Website ini dapat diakses dengan bebas dan memiliki implikasi penting baik bagi pelajar maupun tenaga pengajar. GeoGebra menawarkan peluang kuat untuk membuat pembelajaran yang interaktif baik pada lingkungan online maupun tidak online.

Menurut Hohenwarter et al. (2008: 1), GeoGebra adalah program komputer untuk pengajaran dan pembelajaran matematika yang dilengkapi fitur geometri, aljabar, dan kalkulus yang saling terhubung dan mudah digunakan. Sejalan dengan hasil penelitian yang dilakukan oleh Wijaya et al. (2020: 15) bahwa GeoGebra dapat digunakan pada pembelajaran geometrid an aljabar.

Mahmudi (2011: 3) mengemukakan beberapa pemanfaatan program GeoGebra dalam pembelajaran matematika adalah sebagai berikut:

1. Dapat menghasilkan lukisan-lukisan geometri dengan cepat dan teliti dibandingkan dengan menggunakan pensil, penggaris, atau jangka

2. Adanya fasilitas animasi dan gerakan-gerakan manipulasi (dragging) pada program GeoGebra dapat memberikan pengalaman visual yang lebih jelas kepada siswa dalam memahami konsep geometri

3. Dapat dimanfaatkan sebagai balikan/evaluasi untuk memastikan bahwa lukisan yang telah dibuat benar 
4. Mempermudah guru/siswa untuk menyelidiki atau menunjukkan sifat-sifat yang berlaku pada suatu objek geometri.

Geogebra sangat cocok untuk digunakan bagi mahasiswa program S1 terutama bagi mahasiswa jurusan pendidikan khususnya mahasiswa PGSD dimana nantinya dapat menjadi modal dan sangat bermanfaat untuk dipraktekan saat mengajarkan anak sekolah dasar.

Sedangkan menurut Fahlberg-Stojanovska, L., \& Trifunov (2010: 54) mengemukakan: "with help of the Geogebra, students use dynamic exploration to significantly and vividly improve their total undestanding of compass and straightedge constructive tasks. They are better able to understand the discussion and analyses and procedure for construction. Therefore, we can say that resolving these tasks using geogebra improves the percentage of correctly and completely solved constructive tasks, which is our goal."

Penggunaan GeoGebra dapat mendorong pemahaman saat diskusi, menganalisis dan tahapan dalam mengkonstruksikan kemampuan mahasiswa. GeoGebra dapat dimanfaatkan sebagai media pembelajaran matematika untuk mendemostrasikan dan menvisualisasikan objek-objek yang abstrak. GeoGebra bagus untuk digunakan bagi tenaga pengajar dan pelajar terutama video hasil GeoGebra ditampilkan bagi calon guru sekolah dasar, dimana pada penelitian ini akan dilihat kemampuan matematis mahasiswa dalam penggunaan media berbasis GeoGebra. Kemampuan matematis yang akan dinilai pada penelitian ini merajuk pada kemampuan matematis yng dikutip dari National Council of Teacher of Mathematics (NCTM).

NCTM (National Council of Teacher of Mathematics) (NCTM, 2000) menetapkan lima kemampuan standar yang harus dimiliki dalam belajar matematika yaitu kemampuan pemecahan masalah (problem solving), kemampuan penalaran (reasoning), kemampuan komunikasi (cummunication), kemampuan membut koneksi (connection), dan kemampuan representasi (representation). Berdasarkan lima kemampuan matematis yang ditetapkan NCTM, penelitian ini hanya memfokuskan pada tiga kemampuan yaitu kemampuan komunikasi (cummunication), kemampuan membut koneksi (connection), dan kemampuan representasi (representation) dikarenakan ketiga kemampuan ini digunakan saat penggunaan media pembelajaran matematika.

Komunikasi merupakan proses penyampaian pesan kepada orang lain untuk memberitahukan atau mengubah sikap, pendapat, atau perilaku secara lisan maupun melalui media. Kemampuan komunikasi matematika yang digunakan pada penelitian ini diadaptasi dari Cai, Lane, dan Jakabesin (1996), apabila memenuhi indikator kemampuan menggambar (drawing), kemampuan menulis (written text), kemampuan mengekspresikan matematika (mathematical expression) (Halmaheri, 2004).

Indikator komunikasi matematis yang digunakan pada penelitian ini adalah indikator komunikasi yang dikemukakan oleh Kustiawati (2017: 115): 
1. Written text dengan memberikan jawaban dengan bahasa sendiri, membuat model situasi atau persoalan menggunakan tulisan dan aljabar, menjelaskan dan membuat pertanyaan tentang matematika yang telah dipelajari, mendengarkan, mendiskusikan, dan menulis tentang matematika, menyusun argument dan generalisasi.

2. Drawing merupakan merefleksikan benda-benda nyata, gambar, dan diagram ke dalam ide-ide matematika dan sebaliknya.

3. Mathematical expression merupakan mengekspresikan konsep matematika dengan menyatakan peristiwa sehari-hari dalam bahasa atau symbol matematika.

Koneksi atau connection yang artinya adalah hubungan atau keterkaitan. Koneksi matematika dapat diartikan sebagai keterkaitan secara internal maupun eksternal. Keterkaitan secara internal mencakup keterkaitan konsep-konsep matematika yaitu hubungan dengan matematika itu sendiri, sedangkan keterkaita eksternal mencakup keterkaitan antara matematika dengan kehidupan sehari-hari.

NCTM (2000: 64) memaparkan indikator untuk kemampuan koneksi matematika sebagai berikut:

1. Mengenali dan memanfaatkan hubungan-hubungan atara garasan dalam matematika

2. Memahami bagaimana gagasan-gagasan dalam matematika saling berhubungan dan mendasari satu sama lain untuk menghasilkan suatu keutuhan koheren

3. Mengali dan menerapkan matematika dalam konteks-konteks di luar matematika

Syafri (2017: 54) mengemukakan bahwa kemampuan representasi merupakan suatu kemampuan matematika dengan mengungkapkan ide-ide matematika (masalah, pernyataan, definisi, dan lain-lain) dalam berbagai cara. Indikator kemampuan representasi yang digunakan menggunakan indikator yang dikemukakan oleh Oktaria et al. (2016: 100) meliputi: 1) menjelaskan secara matematis, masuk akal dan tersusun sistematis; 2) menggambar grafik persamaan garis beserta unsur-unsurnya secara lengkap dan benar untik mencari himpunan penyelesaiannya; 3) membuat model matematika.

Mata kuliah matematika umumnya ada disetiap program studi perguruan tinggi terutama pada program studi pendidikan guru sekolah dasar. Pada program studi pendidikan guru sekolah dasar STKIP Syekh Manshur terdapat empat mata kuliah matematika yaitu konsep dasar matematika I, konsep dasar matematika II, pendidikan matematika I, dan pendidikan matematika II. Keempat mata kuliah ini berisikan pembagian materi matematika ditingkat sekolah dasar. Berdasarkan pengalaman peneliti dari tahun 2018 mengampu mata kuliah konsep dasar matematika I, konsep dasar matematika II, dan pendidikan matematika II sangat diperlukan penggunaan media pembelajaran interaktif untuk melihat kemampuan matematis mahasiswa serta meningkat motivasi dan partisipasi mahasiswa selama mengikuti perkuliahan yang berhubungan dengan matematika.

Melalui analisis kemampuan matematis mahasiswa dalam penggunaan media berbasis GeoGebra, maka diharapkan mahasiswa terlatih dan bekal inisiatif untuk menggunakan media pembelajaran matematika saat menjadi seorang guru di sekolah dasar. Berdasarkan uraian tersebut maka peneliti melakukan penelitian dengan judul "Analisis Kemampuan Matematis Mahasiswa Pendidikan Guru 
Sekolah Dasar STKIP Syekh Manshur terhadap Penggunaan Media Berbasis GeoGebra.

\section{METODE}

Jenis penelitian ini menggunakan pendekatan penelitian kualitatif dengan metode deskriptif analitis. Metode deskriptif analitis bersifat memamparkan sejelas-jelasnya tentang objek yang diteliti menggambarkan data secara keseluruhan, sistematis, dan akurat. Teknik pengumpulan data dalam penelitian ini adalah dokumentasi, observasi dan tes. Tahapan dari teknik analisis data yang dilakukan yaitu melakukan pengumpulan data, dan melakukan analisis kemampuan matematis mahasiswa. Populasi pada penelitian ini adalah mahasiswa program studi Pendidikan Guru Sekolah Dasar STKIP Syekh Manshur. Sampel yang diambil adalah semester 4 mata kuliah Pendidikan Matematika II sebanyak 12 orang tahun akademik genap 2019/2020. Penelitian dilakukan terhadap soal-soal hasil tes, dan menarik kesimpulan dari hasil penelitian secara deskriptif. Instrumen yang digunakan pada penelitian ini adalah tes kemampuan matematis, yang terdiri dari 4 butir soal yang mencakup kemampuan komunikasi, koneksi, dan representasi matematis. Berikut bagan alur penelitian pada gambar 1 dan roadmap penelitian pada gambar 2 .
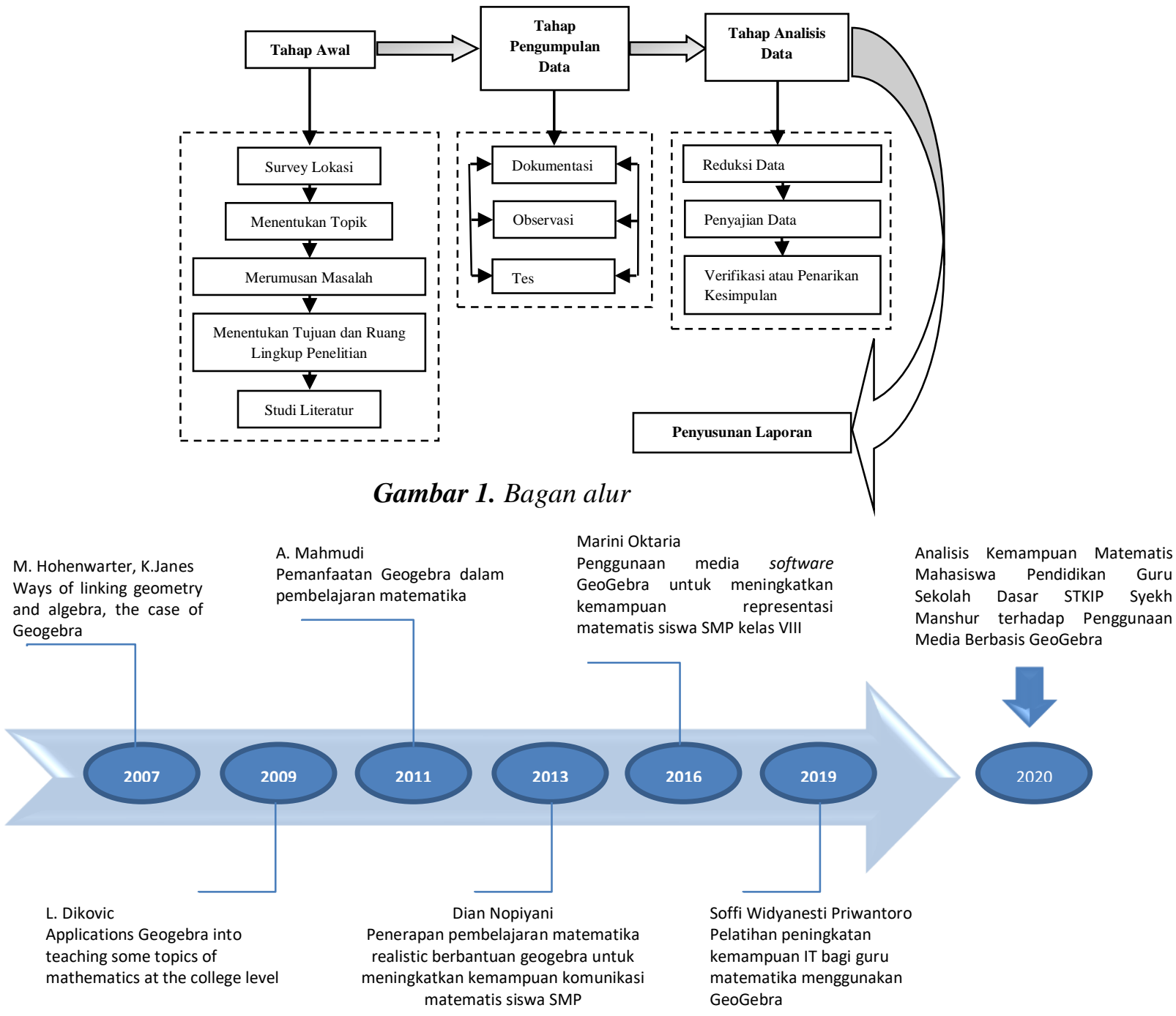

Gambar 2. Roadmap penelitian 
Tabel 1.

Rubrik kemampuan komunikasi matematis yang digunakan

\begin{tabular}{|c|c|c|c|}
\hline Skor & $\begin{array}{c}\text { Menulis } \\
\text { (Written Text) }\end{array}$ & $\begin{array}{l}\text { Menggambar } \\
\text { (Drawing) }\end{array}$ & $\begin{array}{c}\text { Ekspresi Matematis } \\
\text { (Mathematical } \\
\text { Expression) }\end{array}$ \\
\hline 0 & \multicolumn{3}{|c|}{$\begin{array}{l}\text { Tidak ada jawaban, kalaupun ada hanya memperlihatkan tidak memahami konsep } \\
\text { sehingga informasi yang diberikan tidak berarti apa-apa }\end{array}$} \\
\hline 1 & $\begin{array}{l}\text { Hanya sedikit dari } \\
\text { penjelasan yang benar }\end{array}$ & $\begin{array}{l}\text { Hanya sedikit dari } \\
\text { gambar, diagram, atau } \\
\text { tabel yang benar }\end{array}$ & $\begin{array}{l}\text { Hanya sedikit dari model } \\
\text { matematika yang benar }\end{array}$ \\
\hline 2 & $\begin{array}{l}\text { Penjelasan secara matematis } \\
\text { masuk akal namun hanya } \\
\text { sebagian lengkap dan benar }\end{array}$ & $\begin{array}{l}\text { Melukiskan diagram, } \\
\text { gambar, atau tabel } \\
\text { namun kurang lengkap } \\
\text { dan benar }\end{array}$ & $\begin{array}{ll}\text { Membuat model } \\
\text { matematika dengan benar, } \\
\text { namun salah dalam } \\
\text { mendapatkan solusi }\end{array}$ \\
\hline 3 & $\begin{array}{l}\text { Penjelasan secara matematis } \\
\text { masuk akal dan benar, } \\
\text { meskipun tidak tersusun } \\
\text { secara logis atau terdapat } \\
\text { sedikit kesalahan bahasa }\end{array}$ & $\begin{array}{l}\text { Melukiskan diagram, } \\
\text { gambar, atau tabel } \\
\text { secara lengkap } \\
\text { benar }\end{array}$ & $\begin{array}{l}\text { Membuat model } \\
\text { matematika dengan benar, } \\
\text { kemudian melakukan } \\
\text { perhitungan atau } \\
\text { mendapatkan solusi secara } \\
\text { benar dan lengkap }\end{array}$ \\
\hline 4 & $\begin{array}{l}\text { Penjelasan secara matematis } \\
\text { masuk akal dan jelas serta } \\
\text { tersusun secara logis }\end{array}$ & & \\
\hline
\end{tabular}

(Halmaheri, 2004)

Tabel 2.

Rubrik kemampuan koneksi matematis yang digunakan

\begin{tabular}{|l|c|}
\hline \multicolumn{1}{|c|}{ Reaksi Terhadap Soal/Masalah } & Skor \\
\hline Tidak ada jawaban & 0 \\
\hline $\begin{array}{l}\text { Jawaban hampir tidak mirip/sesuai dengan pertanyaan, persoalan atau dengan } \\
\text { masalah }\end{array}$ & 1 \\
\hline $\begin{array}{l}\text { Jawaban ada beberapa yang mirip/sesuai dengan pertanyaan, persoalan atau } \\
\text { dengan masalah tetapi koneksinya tidak jelas }\end{array}$ & 2 \\
\hline $\begin{array}{l}\text { Jawaban ada beberapa yang mirip/sesuai dengan pertanyaan, persoalan atau } \\
\text { dengan masalah dan koneksinya jelas tetapi kurang lengkap }\end{array}$ & 3 \\
\hline $\begin{array}{l}\text { Jawaban mirip/sesuai dengan pertanyaan, persoalan atau dengan masalah tetapi } \\
\text { kurang lengkap }\end{array}$ & 4 \\
\hline $\begin{array}{l}\text { Jawaban mirip/sesuai dengan pertanyaan, persoalan atau dengan masalah } \\
\text { secara lengkap }\end{array}$ & 5 \\
\hline
\end{tabular}

Ramdani, (2012: 45)

Tabel 3.

Rubrik kemampuan representasi matematis yang digunakan

\begin{tabular}{|c|c|c|c|}
\hline \multirow{2}{*}{ Skor } & \multicolumn{3}{|c|}{ Indikator } \\
\hline & Menjelaskan & Menggambar & Ekspresi Matematis \\
\hline 0 & $\begin{array}{l}\text { Tidak ada jawaban, kal } \\
\text { konsep sehingga inform }\end{array}$ & $\begin{array}{l}\text { pun ada hanya memp } \\
\text { yang diberikan tidak b }\end{array}$ & $\begin{array}{l}\text { hatkan ketidakpahaman ten } \\
\text { rti apa-apa }\end{array}$ \\
\hline 1 & $\begin{array}{l}\text { Hanya sedikit dari } \\
\text { penjelasan yang benar }\end{array}$ & $\begin{array}{l}\text { Hanya sedikit dari } \\
\text { gambar, diagram, atau } \\
\text { tabel yang benar }\end{array}$ & $\begin{array}{l}\text { Hanya sedikit dari model } \\
\text { matematika yang benar }\end{array}$ \\
\hline 2 & Penjelasan & Melukiskan & Menemukan \\
\hline
\end{tabular}




\begin{tabular}{|c|c|c|c|}
\hline & $\begin{array}{l}\text { matematis masuk akal } \\
\text { namun hanya sebagian } \\
\text { lengkap dan benar }\end{array}$ & $\begin{array}{l}\text { atau gambar, namun } \\
\text { kurang lengkap dan } \\
\text { benar }\end{array}$ & $\begin{array}{lcc}\text { matematika } & \text { dengan } & \text { benar, } \\
\text { namun salah } & \text { dalam } \\
\text { mendapatkan solusi } & \\
\end{array}$ \\
\hline 3 & $\begin{array}{lr}\text { Penjelasan } & \text { secara } \\
\text { matematis masuk akal, } \\
\text { meskipun tidak } \\
\text { tersusun secara logis } \\
\text { atau terdapat sedikit } \\
\text { kesalahan bahasa }\end{array}$ & $\begin{array}{l}\text { Melukiskan diagram } \\
\text { atau gambar secara } \\
\text { lengkap dan benar }\end{array}$ & $\begin{array}{lr}\text { Menemukan } & \text { model } \\
\text { matematika dengan benar, } \\
\text { kemudian } \\
\text { perhitungan atau mendakukan } \\
\text { solusi secara benar dan } \\
\text { lengkap }\end{array}$ \\
\hline 4 & $\begin{array}{l}\text { Penjelasan secara } \\
\text { matematis masuk akal } \\
\text { dan jelas serta tersusun } \\
\text { secara logis }\end{array}$ & $\begin{array}{lr}\text { Melukiskan } & \text { diagram } \\
\text { atau gambar secara } \\
\text { lengkap, benar dan } \\
\text { sistematis }\end{array}$ & $\begin{array}{l}\text { Menemukan } \\
\text { matematika dengan benar } \\
\text { kemudian melakukan } \\
\text { perhitungan atau mendapatkan } \\
\text { solusi secara benar dan } \\
\text { lengkap secara sistematis }\end{array}$ \\
\hline
\end{tabular}

\section{HASIL}

Analisis data kemampuan komunikasi, kemampuan koneksi dan kemampuan representasi matematis mahasiswa diperoleh melalui tes berupa soal esai yang dilakukan melalui laman website GeoGebra Classroom www.geogebra.org/u/perkuliahanmatematika yang dilakukan dengan membagikan link dan kode akses untuk masuk ke GeoGebra Classroom. Terlebih dahulu, tes divalidasi oleh pakar bidang pendidikan matematika, pakar bidang teknologi pendidikan, dan pakar bidang rekayasa perangkat lunak dan komunikasi visual. Beberapa soal diadaptasi dari pengembangan soal interaktif yang dikembangkan oleh Nasution (2018) dan tim pengembang soal GeoGebra lainnya.

\section{Tabel 4.}

Berikut soal yang diberikan kepada sampel.

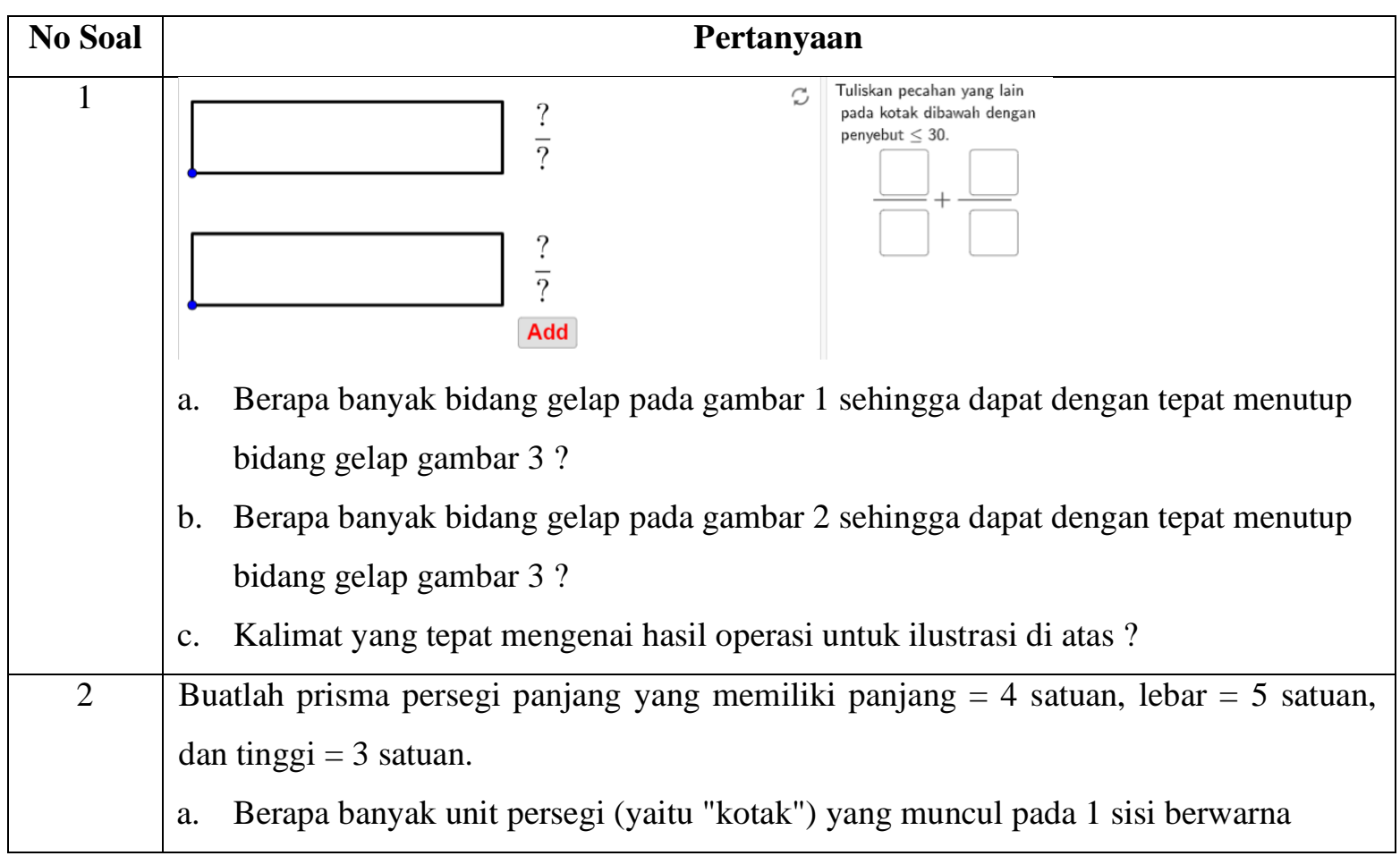




\begin{tabular}{|c|c|}
\hline & $\begin{array}{l}\text { merah muda? Berapa banyak unit persegi (yaitu "kotak") yang muncul pada } 1 \\
\text { permukaan emas? Berapa banyak unit persegi (yaitu "kotak") yang muncul di } 1 \text { sisi } \\
\text { putih? } \\
\text { b. Gunakan jawaban Anda untuk (1) untuk menentukan TOTAL AREA } \\
\text { PERMUKAAN dari prisma persegi panjang ini. Yaitu, berapa banyak unit persegi, } \\
\text { atau bujur sangkar, yang menutupi SELURUH PERMUKAAN prisma persegi } \\
\text { panjang ini? } \\
\text { Sekarang buat prisma persegi panjang yang memiliki panjang = } 8 \text { satuan, lebar = } 3 \\
\text { satuan, dan tinggi = 5 satuan. } \\
\text { c. Berapa banyak unit persegi (yaitu "kotak") yang muncul pada } 1 \text { sisi berwarna } \\
\text { merah muda? Berapa banyak unit persegi (yaitu "kotak") yang muncul pada } 1 \\
\text { permukaan emas? Berapa banyak unit persegi (yaitu "kotak") yang muncul di } 1 \text { sisi } \\
\text { putih? } \\
\text { d. Gunakan jawaban Anda untuk (3) untuk menentukan TOTAL LUAS } \\
\text { PERMUKAAN dari prisma persegi panjang ini. Yaitu, berapa banyak satuan } \\
\text { bujursangkar, atau bujur sangkar, yang menutupi SELURUH PERMUKAAN } \\
\text { prisma persegi panjang ini? } \\
\text { e. Tanpa mencari apa pun di tab lain di browser internet Kamu, jelaskan bagaimana } \\
\text { kamu dapat menentukan total luas permukaan (jumlah persegi) yang menutupi } \\
\text { seluruh permukaan prisma persegi panjang ini. Lebih spesifik! }\end{array}$ \\
\hline 3 & $\begin{array}{l}\text { Pada gambar di bawah, sebuah transversal } \\
\text { memotong } 2 \text { garis sejajar. Gunakan titik dan } \\
\text { penggeser untuk memindahkannya. Kemudian, } \\
\text { gunakan busur derajat untuk mencari ukuran dari } \\
8 \text { sudut yang ditunjukkan. Screeanshot hasil yang } \\
\text { kamu lakukan, dan tuliskan jawabanmu. }\end{array}$ \\
\hline 4 & $\begin{array}{l}\text { Sebuah taman akan dibuat dengan bentuk persegi panjang dengan ukuran panjang dan } \\
\text { lebarnya merupakan bilangan bulat. Jika keliling taman tersebut harus } 24 \text { meter. } \\
\text { a. Ada berapa banyak taman yang berbentuk persegi panjang yang dapat dibuat } \\
\text { dengan ukuran yang berbeda? } \\
\text { b. Apabila taman tersebut akan ditanami rumput dan jika biaya rumput tiap meter } \\
\text { perseginya Rp. 15.000, berapakah jumlah minimum dan maksimum uang yang } \\
\text { dikeluarkan? }\end{array}$ \\
\hline
\end{tabular}

Penjelasan mengenai kemampuan matematis mahasiswa dapat dilihat dari hasil jawaban tes akhir yang diberikan. 


\section{Soal nomor 1}

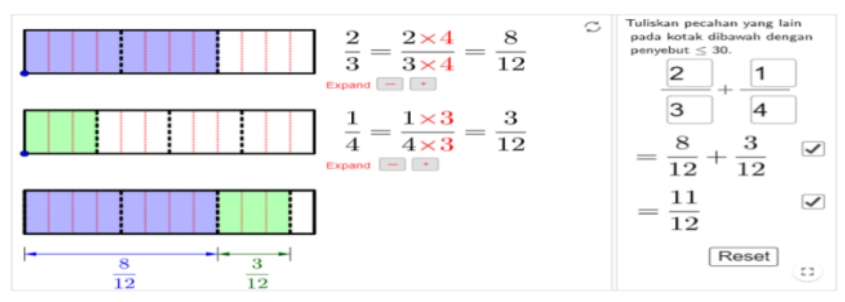

3.

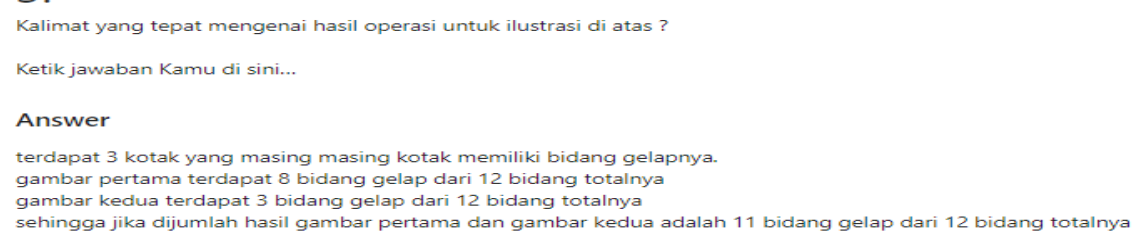

Gambar 3. Jawaban salah satu mahasiswa untuk soal nomor 1.

\section{Analisis Kemampuan Komunikasi Matematis}

Berdasarkan gambar 3, terlihat bahwa jawaban yang salah satu mahasiswa berikan cukup mampu dalam memberikan penjelasan secara matematis masuk akal dan jelas serta tersusun secara logis, dimana mencapai skor 4 dalam kriteria pemberian skor kemampuan komunikasi matematis. Dari 12 mahasiswa, ada 6 orang mencapai skor 4, 3 orang mencapai skor 3, dan 4 orang mencapai skor 2.

\section{Analisis Kemampuan Koneksi Matematis}

Untuk kemampuan koneksi matematis pada gambar 3, mahasiswa memperoleh skor 5 dengan memberikan jawaban mirip/sesuai dengan masalah yang diberikan secara lengkap. Dari 12 mahasiswa, ada 6 orang mencapai skor 5, 3 orang mencapai skor 4, dan 3 orang mencapai skor 3 .

\section{Analisis Kemampuan Representasi Matematis}

Kamampuan representasi untuk jawaban pada gambar 3 mencapai skor 3 dengan indikator menjelaskan secara matematis masuk akal, meskipun tidak tersusun secara logis dan terdapat sedikit kesalahan pada bahasa 6 dari 12 mahasiswa mendapatkan skor 3, 3 orang mencapai skor 2, dan 3 orang mencapai skor 1.

\section{Soal nomor 2}

\section{Analisis Kemampuan Komunikasi Matematis}

Gambar 4 memperlihatkan bahwa jawaban dari salah satu mahasiswa mampu memiliki kemampuan ekspresi matematis dimana mahasiswa dapat membuat model matematika dengan benar, kemudian melakukan perhitungan secara benar dengan skor yang diperoleh adalah 3 dalam kriteria pemberian skor kemampuan komunikasi matematis. Dari 12 mahasiswa, ada 3 orang mencapai skor 3, 2 orang mencapai skor 2, dan sisanya tidak memberikan jawaban. Hal ini menggambarkan bahwa hanya beberapa mahasiswa dapat melakukan eskpresi matematis dalam bentuk model matematika dengan benar. 


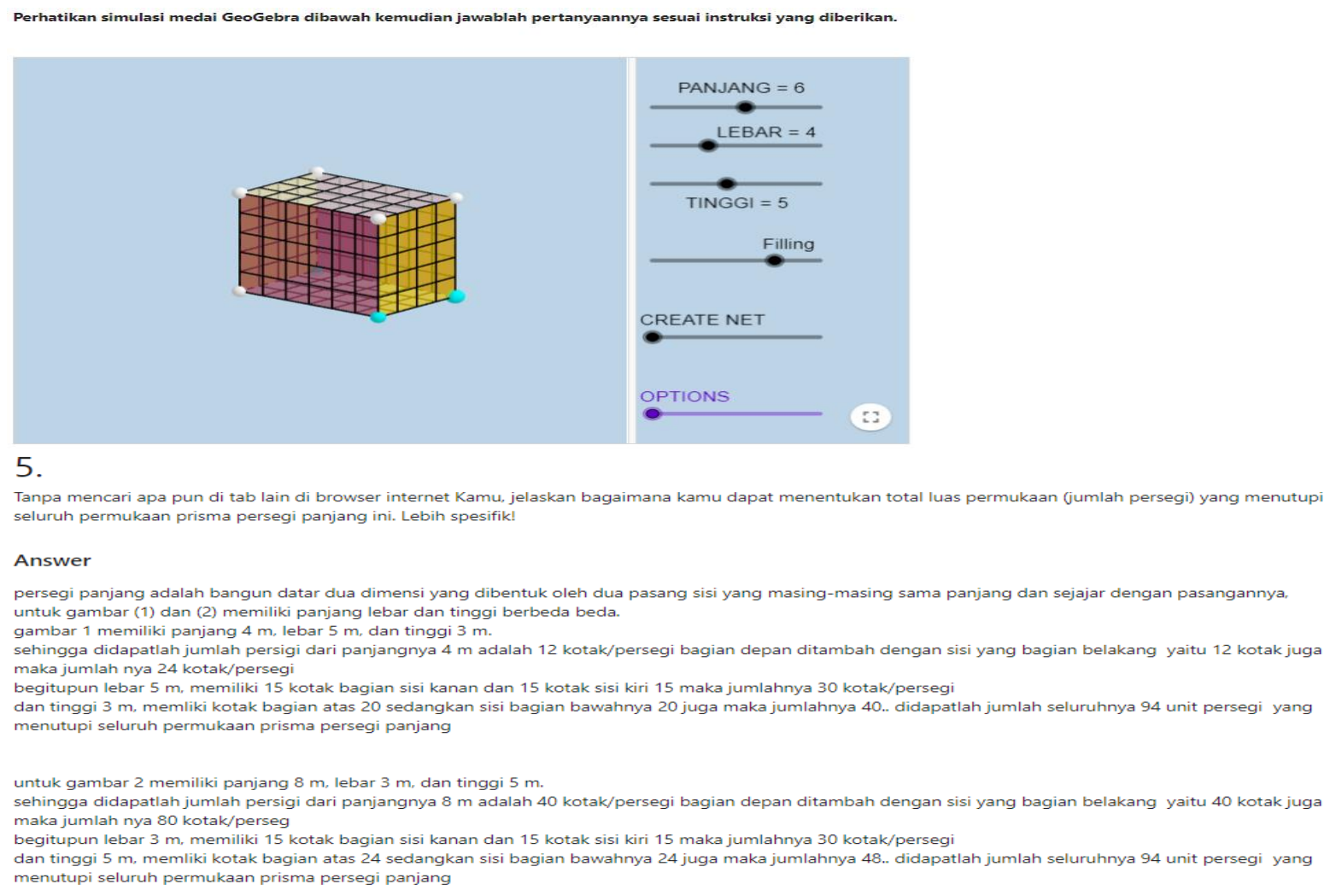

Gambar 4. Jawaban untuk soal nomor 2 dari salah satu mahasiswa.

\section{Analisis Kemampuan Koneksi Matematis}

Untuk kemampuan koneksi matematis pada gambar 4, terlihat bahwa mahasiswa dapat mencapai indikator kemampuan koneksi matematis dalam bentuk memberikan jawaban mirip/sesuai dengan pertanyaan secara lengkap.

\section{Analisis kemampuan representasi matematis}

Kamampuan representasi yang mahasiswa berikan pada gambar 4 telah mencapai indikator kemampuan menemukan model matematika dengan benar kemudian dapat melakukan perhitungan secara benar tetapi belum sistematis sebanyak 3 orang dengan skor pencapaian yaitu 3 .

\section{Soal nomor 3}

Sedangkan untuk gambar 5, mahasiswa diberikan permasalahan dalam melakukan perhitungan besar sudut dengan menggunakan busur tetapi pada aplikasi GeoGebra. Berikut beberapa ilustrasi jawaban yang diberikan oleh beberapa mahasiswa.
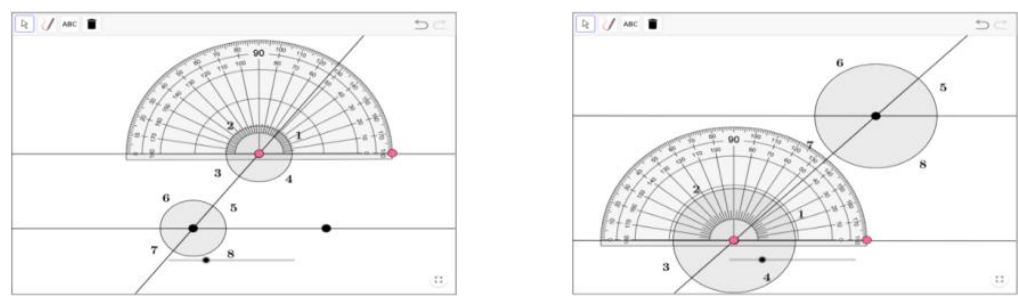

Gambar 5. Beberapa bentuk pergeseran gambar untuk soal nomor 3.

Pada aplikasi GeoGebra untuk soal nomor 5, mahasiswa dapat melakukan perubahan mengenai besar 
sudut pada masing-masing mahasiswa karena diberikan tombol dimana mahasiswa dapat melakukan klik darg untuk menggeser perpindhan gambar pada posisi tertentu., sehingga jawaban yang diberikan bisa beragam disesuaikan dengan persegesarn soal yang diberikan.

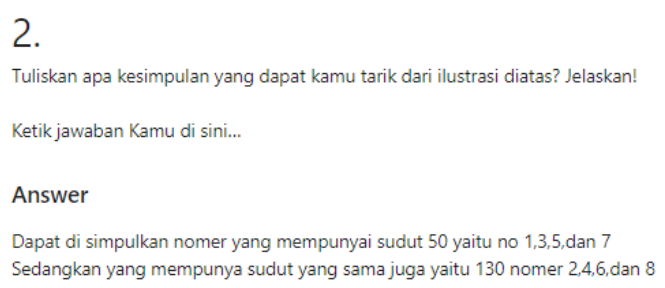

Gambar 6. Jawaban salah satu mahasiswa untuk soal nomor 3

\section{Analisis Kemampuan Komunikasi Matematis}

Indikator kemampuan komunikasi matematis yang dapat dicapai terkait gambar 6 hanya sampai pada pemberian penjelasan secara matematis masuk akal namun hanya sebagian lengkap dan benar. Dari 12 mahasiswa, tidak ada yang mencapai skor tertinggi dan hanya ada 5 mahasiswa yang mencapai skor 3, 5 orang mencapai skor 2, dan sisanya tidak memberikan jawaban.

\section{Analisis Kemampuan Koneksi Matematis}

Kemampuan koneksi terkait jawaban pada gambar 6, mahasiswa ini hanya mampu memberikan jawaban yang beberapa yang sesuai dengan pertanyaan dengan koneksi yang jelas tetapi kurang lengkap, karena kesimpulan secara general yang dapat diambil dari permasalahan yang diberikan tidak diberikan. Dari 12 mahasiswa, skor tertinggi yang didapatkan dari rubrik kemampuan koneksi matematis hanya mencapai 4 dan hanya 5 mahasiswa yang dapat mencapainya.

\section{Analisis kemampuan representasi matematis}

Jawaban yang diberikan pada gambar 6, mahasiswa ini hanya mampu memberikan penjelasan secara matematis masuk akal namun hanya sebagian lengkap dan benar, dengan demikian skor indikator yang didapatkan hanya mencapai 2 .

\section{Soal nomor 4}

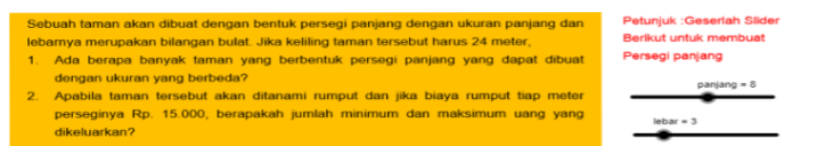

Reherana iaxsahan vano diherikan mahacicrx/a.

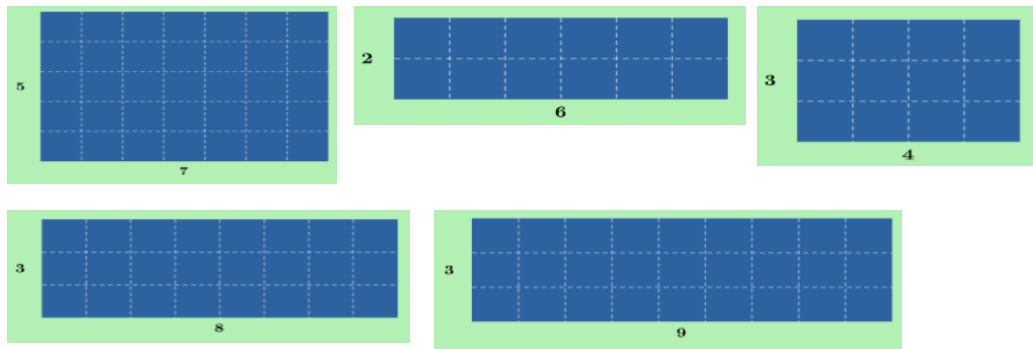

Gambar 7. Jawaban salah satu mahasiswa untuk soal nomor 4 


\section{Analisis Kemampuan Komunikasi Matematis}

Pada soal nomor 7, indikator dari kemampuan komunikasi yang diinginkan adalah kemampuan menggambar (drawing). Umumnya, bebrapa mahasiswa sudah mampu meluskiskan gambar secara benar namun hanya beberapa yang dapat melukiskan semua kemungkinan gambar yang diinginkan untuk menjawab pemasalahan secara lengkap. Dari 12 mahasiswa ada 6 yang dapat memberikan semua kemungkinan jawaban yang diminta, 4 tidak memberikan semua kemungkinan jawaban secara lengkap, dan sisinya memberikan jawaban yang tidak tepat.

\section{Analisis kemampuan koneksi matematis}

1.

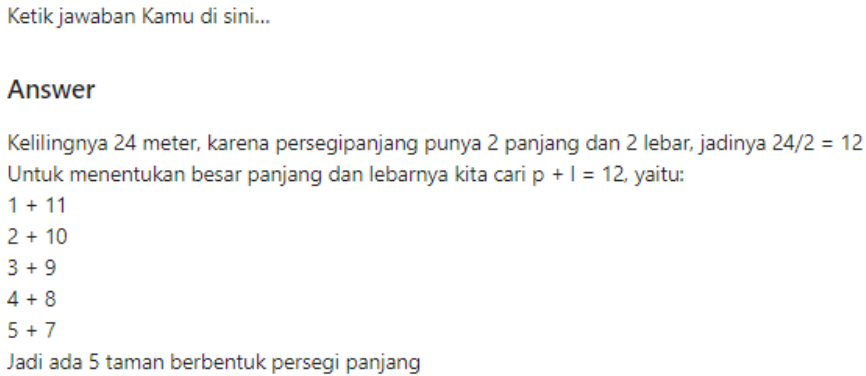

2.

Ketik jawaban Kamu di sini...

Answer

$1 \times 11=11 \times 15000=165000$ minimal

$2 \times 10=20 \times 15000=300000$

$3 \times 9=27 \times 15000=405000$

$4 \times 8=32 \times 15000=480000$

$5 \times 7=35 \times 15000=525000$ maksimal

Gambar 8. Jawaban salah satu mahasiswa untuk soal nomor 4

Jika dilihat dari rubrik kemampuan koneksi matematis, jawaban pada gambar 8 menjabarkan jawaban yang sesuai dengan permasalahan yang diberikan secara lengkap tetapi belum sistemtis, skor yang diperoleh 5 orang dengan skor 5, 4 orang mendapatkan skor 3, dan 2 orang mendapatkan skor 1 dikarenakan jawaban yang diberikan hampir tidak sesuai dengan masalah yang diberikan.

\section{Analisis kemampuan representasi matematis}

Untuk menganalisis kemampuan representasi matematis kembali dilihat pada gambar 7 dan gambar 8 , beberapa mahasiswa sudan mampu memberikan penjelasan secara matematis masuk akal dan jelas serta tersusun secara logis serta dapat melukis gambar secara lengkap dan benar.

\section{KESIMPULAN}

Berdasarkan hasil analisis data dan pembahasan yang dikemukakan, beberapa mahasiswa program studi pendidikan guru sekolah dasar sudah memenuhi indikator dari kemampuan komunikasi, koneksi, dan representasi matematis. Dari data analisis kemampuan matematis diperoleh kesimpulan bahwa mahasiswa terkendala dalam membuat permodelan matematika sehingga masih banyak yang belum mencapai indikator ekpresi dalam komunikasi matematis. Begitu juga dengan kemampuan representasi matematis dimana adanya kebingungan dalam permodelan, namun sudah mampu melukiskan gambar dan memberikan penjelasan dengan benar. Sementara, kemampuan koneksi ratarata memberikan jawaban sesuai dengan permasalahan tetapi kurang lengkap. Peneliti menyarankan 
kepada penelitian selanjutnya dalam penggunaan GeoGebra Classroom diharapkan juga membuat lembar kerja tertulis dan mempraktekan dengan materi yang lain.

\section{DAFTAR PUSTAKA}

Arsyad, A. (2011). Media Pengajaran. PT. Raja Grafindo Persada.

Asyura, I. (2017). Pengembangan Media Pembelajaran Interaktif Berbasis Konstruktivisme Pada Materi Prisma dan Limas Di Kelas VIII SMP. Cakrawala Pedagogik, 1(2), 214-228. https://doi.org/10.17605/OSF.IO/Z4B93

Fahlberg-Stojanovska, L., \& Trifunov, Z. (2010). Constructing and exploring triangles with GeoGebra. Annals. Computer Science Series (Anale. Seria Informatică), 8(2), 45-54. https://anale-informatica.tibiscus.ro/download/lucrari/8-2-03-Fahlberg.pdf

Firman, F. (2020). Dampak Covid-19 terhadap Pembelajaran di Perguruan Tinggi. BIOMA: Jurnal Biologi Dan Pembelajarannya.

Fitaloka, T. (2020). Dampak Covid-19 terhadap Perguruan Tinggi. Kompasiana. https://www.kompasiana.com/kknubbangkatanxv/5f34b0276e38335873547482/dampak-covid19-terhadap-perguruan-tinggi

Halmaheri. (2004). Mengembangkan Kemampuan Komunikasi dan Pemecahan Masalah Matematis Siswa SLTP Melalui Strategi Think-Talk-Write dalam Kelompok Kecil. Universitas Pendidikan Indonesia.

Hohenwarter, M., Hohenwarter, J., Kreis, Y., \& Lavicza, Z. (2008). Teaching and calculus with free dynamic mathematics software GeoGebra. 11th International Congress on Mathematical Education.

Hohenwarter, M., Preiner, J., \& Yi, T. (2007). Incorporating GeoGebra into Teaching Mathematics at the College Level. Proceedings of the International Conference on Technology in Collegiate Mathematics (ICTCM).

Kustiawati, D. (2017). PEMBELAJARAN GEOMETRI BERBANTUAN SOFTWARE GEOGEBRA TERHADAP KEMAMPUAN KOMUNIKASI MATEMATIK SISWA. JIPMat. https://doi.org/10.26877/jipmat.v1i2.1237

Mahmudi, A. (2011). Pemanfaatan GeoGebra dalam Pembelajaran Matematika. Seminar Nasional LPM UNY.

Nasution, S. H. (2018). Penggunaan GeoGebra untuk Membuat Soal Interaktif Matematika. 
Analisis Kemampuan Matematis Mahasiswa PGSD Terhadap Penggunaan Geogebra Classroom di Era dan Pasca

Pandemi COVID-19, Ira Asyura, Ratna Dewi

http://fmipa.um.ac.id/wp-content/uploads/2019/10/Matematika-Syaiful-H-Rev-1-13.pdf

NCTM. (2000). Principles and Standards for School Mathematics Overview. Journal of Equine Veterinary Science.

Oktaria, M., Alam, A. K., \& Sulistiawati, S. (2016). Penggunaan Media Software GeoGebra untuk Meningkatkan Kemampuan Representasi Matematis Siswa SMP Kelas VIII. Kreano, Jurnal Matematika Kreatif-Inovatif. https://doi.org/10.15294/kreano.v7i1.5014

Ramdani, Y. (2012). Pengembangan Instrumen dan Bahan Ajar untuk Meningkatkan Kemampuan Komunikasi, Penalaran, dan Koneksi Matematis dalam Konsep Integral. Jurnal Penelitian Pendidikan.

Syafri, F. S. (2017). Kemampuan representasi matematis dan kemampuan pembuktian matematika. Jurnal Pendidikan Matematika.

Wijaya, T. T., Ying, Z., \& Suan, L. (2020). Using Geogebra in Teaching Plane Vector. Journal of Innovative Mathematics Learning. 